\title{
UNDERLYING BELIEFS AND ATTITUDES ABOUT TOPPING TREES
}

\author{
by James R. Fazio and Edwin E. Krumpe
}

\begin{abstract}
Topping trees has long been a problem in community forestry, not only by creating visual blight, but also by endangering the health of trees and the safety of pedestrians and property. Despite regulations in some cities and a long history of educational campaigns, the practice continues. In this study, a survey was conducted in one region of the United States to determine the reasons behind the continuing practice, in part by directly interviewing people who had requested or allowed their shade trees to be topped. The survey investigated attitudes toward topping, knowledge of basic tree care, how the individuals receive advice related to tree care, how their topping service was obtained, and related sociodemographic characteristics. A second survey was conducted among tree care companies in the same study area to allow comparisons and determine policies toward topping.
\end{abstract}

Key Words. Topping; beliefs; attitudes; arborists; urban and community forestry.

In 1907, pioneering arborist John Davey showed photos of topped trees in his book, The Tree Doctor, and railed against the practice as "the work of ignorant tree men." Not mincing words, he wrote, "Nature does not form those beautiful and health-giving tops of shade trees to be cut to pieces to furnish "beer money' for a lot of tree fools" (Davey 1907).

Almost a century later, conscientious arborists are still frustrated when newly topped trees blight the landscape. Today, the reasons for not topping trees go beyond aesthetics. Kaiser et al. (1986) listed four reasons related to tree health and public hazards that are now standard components in public information leaflets and articles: 1) reducing leaf surface results in reducing food supplies to the roots and other remaining parts of the tree, 2) suddenly exposing the bark of interior limbs to direct sunlight can result in scalding, 3) truncating limbs results in a profusion of sprouts that are weakly attached and become dangerous over time, and 4) creating limb stubs renders the exposed wood vulnerable to insect and fungal invasion because the stubs are unable to produce de- fensive chemical barriers or seal over the wound. The economy of using relatively quick and easy topping has also been shown as mythical due to the necessity for frequent follow-up maintenance, increased liability, potential for tree death and removal costs, and the possibility of reduced property resale value (Hagen 1993; Herr 1993; Fazio 1998).

With so many reasons why trees should not be topped, and with such a long history of publicity efforts to prevent this practice, why is it that some homeowners still request or allow their shade trees to be topped? Although there has been much conjecture expressed in response to this troubling question, the purpose of this study was to go directly to such individuals and learn from them the underlying beliefs and attitudes that lead to the continuation of tree topping in our communities. In addition, tree care companies in the study area were asked about their practice of topping and their attitudes toward it, in an attempt to better understand the dynamics of topping as a lingering community forestry problem.

\section{METHODOLOGY}

In the planning stages of this project, it was decided that a small sample of residents with recently topped trees would be personally interviewed in depth rather than attempting to query larger numbers by mailed questionnaires. The sample area was delineated by selecting highway routes radiating from Moscow, Idaho, approximately $240 \mathrm{~km}$ (150 mi) to the north and west, $80 \mathrm{~km}$ (50 mi) east, and $120 \mathrm{~km}$ $(75 \mathrm{mi})$ south. The routes included large and small communities as well as rural areas in between. To identify appropriate individuals along those routes, interviewers would first spot eligible trees-trees on private property with limbs $5 \mathrm{~cm}$ ( 2 in.) in diameter or greater that had received heading cuts (ISA 1995) within the past 3 or 4 years and that were not located under utility lines. To speed the search process in larger cities, municipal foresters were asked for addresses with eligible trees. 
Interviewers then contacted the residents at those houses and asked to interview the person who would make decisions about tree care on the property. If an on-site interview was not possible, a time was arranged for a phone interview and an instruction card was left to aid the respondent in answering the interview questions. The project was identified as "a University of Idaho study of tree care in the area" and the word "topping" was not used, nor were any negative statements made about the practice. At the conclusion of the interview, the respondent was presented with a free gift, an attractive tree identification booklet published by The National Arbor Day Foundation, What Tree Is That?

In a second phase of the project, a questionnaire with a stamped, self-addressed envelope was mailed to all identifiable tree care companies in the study area. Names were obtained from telephone directories and an Internet service, Switchboard.com. In an attempt to evoke candor and ensure anonymity, the mailings were not coded nor was self-identification requested.

\section{WHO TOPS THEIR TREES?}

Interviewers contacted 110 individuals, 83 of whom agreed to participate. Most individuals who refused to participate gave no reason (52\%). Others were too busy $(30 \%)$, ill $(11 \%)$, or had a language barrier (7\%). When interviews were refused, notes were made of the individual's gender, age, and location (rural, small town, or city). Using these characteristics, tests for nonrespondent biases showed no statistically significant difference between people who were interviewed and those who refused. This, of course, strengthens the case for generalizing findings to others within the study's population.

As shown in Table 1, the decision-makers responsible for topped trees tended to be in the older population segments $(58 \%$ over 50 years in age), not highly educated ( $72 \%$ with less than a college degree), and in the lower economic strata ( $57 \%$ with annual household incomes less than US $\$ 40,000$ ). Nearly all were homeowners (96\%) instead of tenants, and-importantly-a large number (26\%) lived in their homes for 4 years or less (mode $=3$ years). The remaining $74 \%$ were spread somewhat evenly across "years in residence" ranging from 5 to 70 years. These data imply that a considerable amount of topping occurs soon after a property is acquired.

In the arborist portion of this study, 53\% of the professionals who responded were of the opinion that homeowners usually choose commercial tree care companies to do the topping, or moonlighters from other trades and professions (21\%). Only one respondent believed that the work was usually done by the property owner. What we found from the residents that we interviewed suggests that nonprofessionals do the actual topping almost as often as it is done by commercial operators. Although $56 \%$ of the time commercial operators were hired (including some moonlighters who were confused by respondents with legitimate tree care professionals and are included in this statistic), $29 \%$ of the topping was done by the property owner, $8.5 \%$ by relatives, and $5 \%$ by friends or neighbors.

When a commercial operator was used, $37 \%$ of the time the firm or person was chosen based on referral by a friend or neighbor. Selections resulting from advertising were the telephone directory (26\%) and newspaper ads ( $9 \%)$. Fourteen percent of the topping resulted from the infamous "knock at the door," and another $2 \%$ from being solicited by telephone. Most of the remaining $12 \%$ can be attributed to homeowners seeing work in progress at another address and contacting the operator.

\section{WHY THEY TOP}

Our study confirmed conjecture by Kaiser et al. (1986) that fear is the primary motivation for topping. A detailed breakdown of reasons given by the

Table 1. Sociodemographic profile of decision-makers responsible for topped trees on private property in the U.S. Inland Northwest. (All data in percentages; $\mathbf{n}=83$.)

\begin{tabular}{llll}
\hline Gender & Age & Highest level of education & $\begin{array}{l}\text { Annual household } \\
\text { income (US } \$)\end{array}$ \\
\hline Male $(55 \%)$ & $18-29(1 \%)$ & Under 12 years $(8.5 \%)$ & $\begin{array}{l}\text { Less than } \$ 20,000(11 \%) \\
\text { Female }(45 \%)\end{array}$ \\
& $30-39(23 \%)$ & High school degree $(63.5 \%)$ & $\$ 20,000-\$ 40,000(46 \%)$ \\
& $40-49(18 \%)$ & College degree $(19.5 \%)$ & $\$ 40,000-\$ 60,000(24 \%)$ \\
& $50-59(12 \%)$ & Advanced degree $(8.5 \%)$ & $\begin{array}{l}\text { Above } \$ 60,000(18 \%) \\
\text { No response }(1 \%)\end{array}$ \\
\hline
\end{tabular}


residents is shown in Table 2 along with a comparison of reasons believed by area arborists. It is important to note that very few of the respondents expressed an opinion that they actually liked the looks of a topped tree or did it for that reason. As can be seen in the following examination of tree knowledge held by residents in the study, it is highly unlikely that those who topped understood the detrimental effects of their decision or that there might be a better way to attain their goals.

\section{KNOWLEDGE OF TREE CARE PRACTICES}

If educational efforts are to be successful in teaching people why they should not top trees, it is important to first know the level of knowledge held by the target group. To do this, we developed an 8-question "test" consisting of both pruning questions and others that might reveal a layperson's knowledge about basic tree care. To conceal the fact that this was a knowledge test, which might lead to embarrassment or reluctance, seven of the questions were presented as seeking an "opinion." A Likert-type scale (where $1=$ strongly agree and $10=$ strongly disagree) was included to allow for strength of the opinion. During data analysis, however, answers were coded either "right" or "wrong" based on whether respondents agreed or disagreed with the statement. The eighth question showed the results of three ways a limb might be pruned (flush, just outside the branch collar and branch bark ridge, and leaving a stub). There was also an option to select "Doesn't matter."

The questions were pretested on actual homeowners and found to be clearly understood. The test was also given to students completing a sophomore-level urban and community forestry course with the results being near-perfect scores.

The results from study participants were not as encouraging. As may be seen in Table 3, the overwhelming majority of laypersons in this study held incorrect beliefs about tree care. Only $6.1 \%$ of the respondents answered more than half the questions correctly. No discernible characteristics were found that would set these individuals apart from the other participants, and in no cases were the strength of their beliefs high on the Likert scale.

Another question devised to determine whether residents understood the effects of topping was "How long do you think it will be until you need to

Table 2. Reasons given for why residents top or allow their trees to be topped.*

\begin{tabular}{|c|c|c|c|c|c|}
\hline Reason & Number & Percentage & Reason & Number & Percentage \\
\hline \multicolumn{3}{|c|}{ Reason conjectured by area arborists } & \multicolumn{3}{|c|}{ Reason given by homeowners/tenants } \\
\hline Tree too big & & $47 \%$ & Tree too big & & $57 \%$ \\
\hline Fear & 8 & & Fear for house & 20 & \\
\hline Safety & 4 & & Too "messy" (leaves) & 7 & \\
\hline Fewer leaves to rake & 1 & & Reduce wind danger & 6 & \\
\hline \multirow[t]{3}{*}{ Not specified } & 10 & & Too much shade & 5 & \\
\hline & & & Dangerous & 2 & \\
\hline & & & Keep it short & 1 & \\
\hline $\begin{array}{l}\text { Ignorance/susceptible to } \\
\text { solicitations }\end{array}$ & 7 & $15 \%$ & & & \\
\hline Storm damage & 4 & $9 \%$ & $\begin{array}{l}\text { Storm damage (broken } \\
\text { and/or dead limbs) }\end{array}$ & 17 & $24 \%$ \\
\hline Routine; "the thing to do" & 4 & $9 \%$ & $\begin{array}{l}\text { Routine; was done previously } \\
\text { previously }\end{array}$ & 4 & $6 \%$ \\
\hline Other & & $20 \%$ & Other & & $13 \%$ \\
\hline Utility lines & 3 & & To prevent aphids & 3 & \\
\hline View enhancement & 3 & & Likes appearance & 2 & \\
\hline Likes appearance & 1 & & Miscellaneous & 5 & \\
\hline Miscellaneous & 3 & & & & \\
\hline Totals & 47 & $100 \%$ & & 72 & $100 \%$ \\
\hline
\end{tabular}

*Trees in this study were specified as those not under or near utility lines. 
Table 3. Tree-care test scores from residents who topped or allowed their trees to be topped.

\begin{tabular}{ll}
\hline Question* & \multicolumn{1}{l}{$\begin{array}{l}\text { Percentage } \\
\text { responding correctly }\end{array}$} \\
\hline $\begin{array}{l}\text { 1. Should trees be fertilized at least once a year? } \\
\text { 2. Will a (topped) tree be safer, i.e., less likely to become a } \\
\text { hazard and hurt someone or damage property? }\end{array}$ & $48 \%$ \\
3. If a tree is (topped), will it be invigorated because its & $4 \%$ \\
$\quad$ roots then have to feed fewer limbs? & $11 \%$ \\
4. If a tree is (topped), will there be a beneficial effect on the & \\
$\quad$ tree from more sunlight getting in? & $5 \%$ \\
5. Is (topping) a good way to prevent insect or disease problems? & $13 \%$ \\
6. Do (topped) branches close over and seal by the growth & \\
of new wood? & $24 \%$ \\
7. Will (topping) result in better root growth? & $7 \%$ \\
8. Proper pruning cut (selection of correct illustration) & $30 \%$ \\
\hline
\end{tabular}

"Questions were actually worded as statements toward which an "opinion" could be expressed. Also, the words "topped" or "topping" were not used. Instead, questions 2-7 were asked in terms of the tree on the person's property that had received "treatment." In all cases, the answers to these questions should be "no."

have the work repeated, and what, if anything, will need to be done?" Eight percent of the respondents did not know and $18 \%$ believed that no future work would be needed. The majority $(67.5 \%)$, however, did understand the resprouting consequences of topping and expected that work would need to be repeated. Of these, most $(63 \%)$ had the rather realistic anticipation of the work needing to be done in 5 years or less. They apparently are willing to pay the $\$ 489$ that was reported as the mean cost (median was $\$ 362$ ) for the topping jobs observed at the participants' residents. Costs of zero were reported by $40 \%$ of the respondents due to having done the work themselves or by enlisting friends or relatives. These were not included in the cost averages.

When asked where they obtain advice on what to do in the way of "caring for their trees," 34\% reported receiving no advice. "Tree care professionals" (loosely defined) were mentioned $41 \%$ of the time, government personnel $13 \%$, friends and neighbors $12 \%$, and relatives $7 \%$. Percentages do not equal 100 because some respondents mentioned more than one source of advice. Government personnel were mentioned by 11 individuals. Nearly all were referring to Cooperative Extension personnel. Only one mentioned a city forester, and two considered utility workers as government personnel. Unfortunately, a check on the tree care knowledge tests of individuals who received advice showed that they ranged from zero correct answers to $37.5 \%$ !
We also asked participants if they had received and read printed material about tree pruning, or had seen anything about it on television or heard anything on the radio. A surprising 58\% said they had read about pruning, $22 \%$ had seen something about it on television, $20 \%$ said they heard about pruning on the radio, and $4 \%$ received information by both television and radio. However, when asked for more specifics, respondents generally could not recall the source. The few who could recall cited literature from the city forester (five people), Cooperative Extension material (five people), and an assortment of other sources such as books from Rodale Press, Readers Digest, Ortho and Sunset, a newspaper article, a tree industry booth at a home show, nursery catalogs, Better Homes and Gardens and Good Housekeeping. Despite recalling exposure to information about pruning, there was no statistically significant difference between the average knowledge scores of these individuals and those who did not report having seen or heard information about pruning.

\section{THE ROLE OF LOCAL ARBORISTS}

An objective of this study was to obtain a profile of how commercial tree care companies in the study area view topping and how their perceptions of the practice compare with those held by residents with topped trees. Some of these data have been reported above. However, in general this was a rather disappointing part of the study, in several ways.

Seventy-five companies were identified through their advertising in phone books. Ten of these did not show addresses and refused to reveal an address when contacted by phone. Of the 65 companies successfully contacted by mailed questionnaire, only 19 responded, for a return of only $29 \%$.

From the responding companies we learned that $37 \%$ of them offered topping as one of their services. Several of the respondents wrote long comments 
about the evils of topping and the companies that aggressively pursue customers to sell this service. Interestingly, only six of the respondents $(32 \%)$ had ISA Certified Arborists in their companies, and none of these offered topping as a service. Of the $13 \mathrm{com}$ panies having no Certified Arborists, 54\% offered topping and $46 \%$ did not. Still, virtually every company would top under some circumstances and all but one reported having a policy pertaining to when they would top a tree. These reported guidelines are listed in Table 4.

In a series of questions designed to probe attitudes toward topping, none of the 19 commercial respondents expressed a belief that "topping has no ill effects on trees." Most (63\%), however, believe that while "topping harms trees, there are reasons to do the work" (undoubtedly those reasons reported in Table 4). Only $58 \%$ believe "there is too much topping being done" and $32 \%$ agreed with the statement that "there is very little topping except under utility lines." Most (53\%) optimistically believe that "the practice of topping is on the decrease," while $11 \%$ feel it is increasing, and the remainder had no opinion about the trend.

\section{CONCLUSIONS AND RECOMMENDATIONS}

The arborists who believe that topping is on the decline are undoubtedly correct. When Davey was writing about the "ignorant and nefarious frauds" of "professional tree men" in 1907, he reported that the capital of Pennsylvania had been almost completely denuded by topping and that tens of thousands of trees had "been ruined" in cities such as Philadelphia. Today, although the truncated tops of shade trees still sporadically appear throughout the United States, particularly in smaller communities and rural areas, there is a concerted effort by enlightened organizations and individuals to eradicate the practice entirely. The question is, How to do that?

The results of this study can be generalized only to residents in the U.S. Inland Northwest, but still may be of help. The inquiry reported here could easily be replicated in other areas and the results would probably be consistent. We offer these comments in that light.

Operators of tree care companies appear to be both a part of the problem and the solution. From the names of companies that residents reported having topped the trees used in this study, it is clear that
Table 4. Policy or guidelines for topping reported by 19 U.S. Inland Northwest tree care companies.

\begin{tabular}{ll}
\hline Guideline & Number reporting \\
\hline If tree is a hazard & 6 \\
Storm-damaged tree & 4 \\
If customer insists & 3 \\
Certain species only & \\
$\quad$ (e.g., poplars and fruit trees) & 3 \\
To open up views & 2 \\
Decision up to arborist & 1 \\
If tree has been topped in past & 1 \\
No policy & 1 \\
\hline
\end{tabular}

there are, in fact, the proverbial rotten apples spoiling the barrel. Regulation through ordinances, licensing, and enforcement may be the only way to deal with operators who work only by knocking on doors, using a phone number and no address, and showing no regard for the welfare of customers or the long-term health of their trees.

Within the more legitimate fraternity of tree care companies, better remedies include the voluntary adoption of policies by all companies placing the practice of topping off limits to its personnel (including off-duty utility personnel) except in rare, justifiable circumstances. An ethics-based prohibition against topping might also be made a condition of certification, as was suggested by one arborist in this study. Another arborist reported that his and other concerned companies produce a newsletter to alert homeowners to the problem of topping. His group has even sponsored ads on city buses in an attempt to raise public consciousness on the issue.

It is clear that communication efforts are still very much needed. Many people, especially older people, are not being reached with information about topping, or are not being convinced to reject topping if they are reached. The content of educational campaigns needs to be directed at the two principal reasons why people top-fear of large trees and misconceptions about the consequences of topping (as shown in Table 3 ). The finding that even people who received information from sources such as Cooperative Extension did poorly on the knowledge test may suggest that message content should be more closely related to the specific needs and fears of the property owner. 
The strategic design of an effective communication campaign is beyond the space limitations of this report. However, one nontraditional target audience did emerge from the data in this study that should be mentioned. In that so much of the topping takes place shortly after a new owner takes possession of a property, real estate agents could be an important conduit of information about responsible ways to prune large trees and how to locate Certified Arborists in the area who would do the work or provide advice.

A plethora of printed literature about topping is available but is apparently not finding its way to the people who can use it. As with most educational campaigns, it cannot be expected that the people who need the information will request it. Efforts need to be redoubled to direct the publications to property owners through aggressive and possibly new and innovative distribution methods.

By refining and increasing educational efforts, the green industry is in a position to make the practice of topping virtually a thing of the past. If this could be accomplished in the next several years, what better tribute could be paid to the pioneering work of John Davey on the 100th anniversary of the publication of The Tree Doctor.

\section{LITERATURE CITED}

Davey, John. 1907. The Tree Doctor-The Care of Trees and Plants. The Saalfield Publishing Co., New York, NY. 235 pp.

Fazio, James R. (Ed.). 1998. Don't Top Trees! Tree City USA Bulletin No. 8, The National Arbor Day Foundation, Lincoln, NE. 8 pp.

Hagen, Bruce. 1993. Why are trees topped? California ReLeaf, California Trees Spring: $1-3$.

Herr, Serena. 1993. The business of butchering trees. California ReLeaf, California Trees Spring:1-4.

International Society of Arboriculture. 1995. Tree-Pruning Guidelines. ISA, Champaign, IL. 15 pp.

Kaiser, C.A., M.L. Witt, J.R. Hartman, R.E. McNiel, and W.C. Dunwell. 1986. Warning: Topping is hazardous to your tree's health! J. Arboric. 12(2):50-52.
Acknowledgements. We wish to express appreciation to Fred Noland and Kelly Lawrence, who conducted the interviews for this study; graduate assistant Brenda Lackey for her assistance in data processing; and the Hyland R. Johns Grant Program of the International Society of Arboriculture for the funding that made this project possible.

Department of Resource Recreation and Tourism College of Forestry, Wildlife and Range Sciences University of Idaho Moscow, ID 83844

\section{Corresponding author: James R. Fazio}

Résumé. Létêtage des arbres a longtemps été un problème dans les communautés, non seulement en créant un saccage visuel, mais aussi en mettant en péril la santé des arbres et la sécurité des passants et des propriétés. En dépit de la réglementation dans certaines municipalités et d'une longue séquence de campagnes d'éducation, cette pratique se poursuit. Dans cette étude, une enquête a été menée dans une région des États-Unis pour déterminer les raisons derrière la poursuite de cette pratique, et ce en partie par des interviews directs auprès des gens qui ont exigé ou permis que leur arbre soit étêté. L'enquête s'est orientée sur les motifs au-delà de l'étêtage, les connaissances de base sur l'entretien des arbres, comment les gens recevaient les avis relativement à l'entretien des arbres, comment ils avaient obtenu leur service d'étêtage, ainsi que sur des caractéristiques sociodémographiques. Une seconde enquête a été menée parmi les entreprises d'entretien d'arbres du même secteur afin de permettre des comparaisons et de déterminer des politiques à propos de l'êtêtage.

Zusammenfassung. Das Kappen von Bäumen ist lange Zeit ein Problem für kommunalen Waldbestand gewesen. Nicht nur, daß es einen optischen Eingriff bedeutet, sondernes gefährdet auch die Baumgesundheit und und die Sicherheit von Passanten und Eigentum. Ungeachtet von Regularien in einigen Städten und einer langen Geschichte von Aufklärung und Fortbildungsangeboten hält diese Praxis an. In dieser Strudie wurde eine Untersuchung in einer Region der USA durchgeführt, um die Hintergründe dieser Praxis zu erkennen. Teilweise wurden dabei die Personen, die ihren Schattenbaum köpfen ließen, direkt 
interviewt. Die Studie untersuchte die Einstellung zum Kappen, Grundwissen über Baumgesundheit, wie die Individuen sich über Baumgesundheit aufklären lassen, wie sie ihre Dienstleistung erhalten haben und verwandte soziodemografische Charakteristika. Eine zweite Studie wurde unter Baumpflegern in der region durchgeführt, um Vergleiche zu ermöglichen und eine Potitik gegen Kappen zu entwickeln.

Resumen. El desmoche de los árboles ha sido un gran problema en la comunidad forestal, no solamente por la creación de la ruina visual, sino también por la afectación de la salud de los árboles, la seguridad de los peatones y la propiedad. A pesar de las regulaciones en algunas ciudades y una larga historia de campañas educativas, la práctica continúa. Se condujo un estudio en una región de los Estados Unidos para determinar las razones detrás de esta práctica, en parte entrevistando directamente a la gente que había solicitado o permitido que sus árboles fueran desmochados. El estudio investigó actitudes hacia el desmoche, el conocimiento del cuidado básico del árbol, cómo reciben las personas recomendaciones acerca del cuidado de los árboles, cómo fue obtenido el servicio de desmoche, y las características sociodemográficas relacionadas. Un segundo estudio fue dirigido hacia las compañias de cuidado de los árboles en la misma área de estudio, para permitir comparaciones y determinar políticas hacia el desmoche. 